University of Nebraska - Lincoln

DigitalCommons@University of Nebraska - Lincoln

Publications from USDA-ARS / UNL Faculty

U.S. Department of Agriculture: Agricultural

Research Service, Lincoln, Nebraska

November 2006

\title{
The circuitous path to the comparison of simulated values from crop models with field observations
}

\author{
Albert Weiss \\ University of Nebraska-Lincoln, aweiss1@unl.edu \\ Wally Wilhelm \\ University of Nebraska-Lincoln, wally.wilhelm@ars.usda.gov
}

Follow this and additional works at: https://digitalcommons.unl.edu/usdaarsfacpub

Part of the Agricultural Science Commons

Weiss, Albert and Wilhelm, Wally, "The circuitous path to the comparison of simulated values from crop models with field observations" (2006). Publications from USDA-ARS / UNL Faculty. 76.

https://digitalcommons.unl.edu/usdaarsfacpub/76

This Article is brought to you for free and open access by the U.S. Department of Agriculture: Agricultural Research Service, Lincoln, Nebraska at DigitalCommons@University of Nebraska - Lincoln. It has been accepted for inclusion in Publications from USDA-ARS / UNL Faculty by an authorized administrator of DigitalCommons@University of Nebraska - Lincoln. 


\title{
CENTENARY REVIEW
}

\section{The circuitous path to the comparison of simulated values from crop models with field observations}

\author{
A. WEISS ${ }^{1}$ AND W. W. WILHELM ${ }^{2 *}$ \\ ${ }^{1}$ School of Natural Resources, University of Nebraska, Lincoln, NE 68583-0987, USA \\ ${ }^{2}$ USDA-ARS, Soil and Water Conservation Research Unit, 120 Keim Hall-UNL, \\ Lincoln, NE 68583-0934, USA
}

(Revised MS received 10 August 2006; First published online 12 October 2006)

\begin{abstract}
SUMMARY
The Journal of Agricultural Science, Cambridge has been a fixture in dissemination of crop simulation models and the concepts and data upon which they are built since the inception of computers and computer modelling in the mid-20th century. To quantify the performance of a crop simulation model, model outputs are compared with observed values using statistical measures of bias, i.e. the difference between simulated and observed values. While applying these statistical measures is unambiguous for the experienced user, the same cannot always be said of determining the observed or simulated values. For example, differences in accessing crop development can be due to the subjectivity of an observer or to a definition that is difficult to apply in the field. Methods of determining kernel number, kernel mass, and yield can vary among researchers, which can add errors to comparisons between experimental observations and simulated results. If kernel moisture is not carefully determined and reported it can add error to values of grain yield and kernels per unit area regardless of the protocol used to collect these data. Inaccurate determination of kernel moisture will also influence computation of grain protein or oil content. Problems can also be associated with input data to the simulation models. Under-reporting of precipitation values from tipping bucket rain gauges, commonly found on automated weather stations, can introduce errors in results from crop simulation models. Using weather data collected too far from an experimental site may compound problems with input data. The importance of accurate soil and weather input data increases as the environment becomes more limiting for plant growth and development. Problems can also arise from algorithms that calculate important parameters in a model, such as daylength, which is used to determine a photoperiod response. Errors in the calculation of photoperiod can be related to the definition of sunrise and sunset and the inclusion or exclusion of civil twilight or to the improper calculation of the solar declination. Even the simple calculation of the daily mean air temperature can have an impact on the results from a non-linear algorithm. During a period when crop simulation modelling is moving in the difficult direction of incorporating genomic-based inputs, the critical importance of careful and accurate collection and reporting of field data and the need to develop robust algorithms that accommodate readily available or easily acquired input data should not be forgotten. As scientists we have an obligation to provide the best available knowledge and understanding as possible. Avoiding potential pitfalls will assist us as we develop new knowledge and understanding and incorporate these concepts into new or modified crop simulation models.
\end{abstract}

\section{INTRODUCTION}

One hundred years in geological time is miniscule, passing without perceptible change. In contrast, 100 years in the life of a scientific journal represents an

* To whom all correspondence should be addressed. Email:wwilhelm1@unl.edu exceptionally long period, characterized by enormous changes in technology, while fundamental problems remain surprisingly similar. As noted in the editorial that began the 100th anniversary volume (Volume 143) of the Journal of Agricultural Science, Cambridge (JAS), issues addressed in the first volume resonate in current articles. The first paper in Volume 1 (Biffen 
1905) discussed the necessity of improving grain end-use quality of British grown wheat through breeding. There was an economic incentive to use solely British wheat, rather than blend this with imported wheat, to produce flour with the required end-use quality characteristics. Other papers in the inaugural issue presented observations on soil management techniques to improve plant growth, to change crop composition, to follow movement of plant nutrients in the environment, and to understand the influence of environment and genetics on crop growth and yield. Papers with similar themes have appeared in recent volumes of JAS, but techniques used have changed greatly from Volume 1 to Volume 144. Crop simulation modelling is one of the new techniques.

Simulation models in agriculture, used as tools for both forecasting and understanding, were developed soon after the first commercial computers became available. An integral part of the development of these models was field observations designed to fill knowledge gaps. Table 1 lists many of the papers that were published in JAS regarding crop models and the observational studies upon which they are based. This list is not exhaustive, but an indication of the wide variety of modelling papers published in JAS. While many papers discuss the problems and concerns associated with model development, the pitfalls involved with model development and assessment have not received as much attention.

A necessary component in the evaluation of a crop simulation model is the comparison of observed and simulated values. This comparison can be quantified using a statistical measure of central tendency and dispersion. That is, measures of the mean and variance. Combinations of these measures, such as mean error, mean absolute error, root mean square error, normalized root mean square error, index of agreement, and modelling efficiency are frequently used (Janssen \& Heuberger 1995). Following this analysis, there is usually an explanation of why the simulated results occurred. When large differences occur between simulated and observed values, a conclusion may be reached that a process is not well understood and further experimental work is required to quantify the variables associated with a process. Conversely, favourable comparisons may imply that a process is satisfactorily understood for that particular modelling application. However, there may be situations where either good or poor agreement between simulated and observed values results from an error in an observation or in the use of an input variable in the simulation model. While one may be able to evaluate the strengths and weaknesses (assumptions) of an algorithm, problems associated with observational errors may be subtle. Similar types of errors may also be associated with model input data. One could easily argue that there are errors in all data and these errors are well known and dealt with by the appropriate experimental and simulation protocols usually described in the Materials and Methods section of a manuscript. In response, one might contend that serious errors can occur when we assume that protocols for measurement procedures for specific parameters are common knowledge and are consistent for a crop, a discipline, or a period of time.

A technological example to illustrate the latter point occurred on 23 September 1999, when the NASA Climate Orbiter crashed, rather than orbited Mars, because one engineering group used English units and another SI units for a key spacecraft operation. A simulation example is provided in McMaster \& Wilhelm (1997) where two accepted methods of calculating thermal time are evaluated, resulting in different values of accumulated thermal time with the same data set. In describing some of these measurement protocols important details may not be adequately explained, which can result in others who follow these protocols making inappropriate assumptions. Carberry (1991) corrected algorithms to simulate leaf area in maize (Zea mays L.) based on initial misinterpretation of parameter definitions in the published documentation of the model. Published algorithms may contain errors. For example, the equation relating phyllochron to daylength at time of crop emergence presented by Baker et al. (1980) contained an error (the slope of the linear relationship was transposed, it was published as 0.62 when it should have been 0.26 per degree day) as noted by McMaster et al. (1991). Though errata and associated correspondence may be published, they may be difficult to locate unless one is a constant reader of the same journal. Furthermore, additional commentary on an article may cause more confusion rather than enhance understanding.

An interesting example of this phenomenon is the publication by Walraven (1978) on the calculation of the elevation and azimuth angles of the sun, which was based on simplified astronomical calculations, with a stated accuracy of $\pm 0.01^{\circ}$. That paper was followed by a series of comments and comments on comments: Walraven (1979), Archer (1980), Wilkinson (1981), Muir (1983), Wilkinson (1983), Ilyas (1983), Pascoe (1984), Ilyas (1984a), Wilkinson (1984), Ilyas (1984b), Kambezidis \& Papanikolaou (1990), and Kambezidis \& Tsangrassoulis (1993). In an attempt to clarify the confusion caused by the first 10 papers, Michalsky (1988a) published a series of algorithms with the same stated accuracy as in Walraven (1978). This publication was followed by Michalsky (1988b), Spencer (1989), and Michalsky (1989) in order to correct and clarify some components of this 'corrected' algorithm.

Workers, who may not appreciate the detail that is required for accurate field-related measurements, may make the majority of these measurements. While 
Table 1. Observational studies supporting crop modelling and crop modelling studies published in JAS from 1970 through 2006 (Volumes 74-144). See References for full details

\begin{tabular}{|c|c|c|}
\hline Author & Year & Title \\
\hline \multicolumn{3}{|l|}{ Observational studies } \\
\hline Willey \& Holliday & 1971 & Plant population and shading studies in barley. \\
\hline Kirby \& Faris & 1972 & The effect of plant density on tiller growth and morphology in barley. \\
\hline Kirby & 1974 & Ear development in spring wheat. \\
\hline $\begin{array}{l}\text { Hadjichristodoulou } \\
\text { et al. }\end{array}$ & 1977 & $\begin{array}{l}\text { Effect of sowing depth on plant establishment, tillering capacity and other agronomic } \\
\text { characters of cereals. }\end{array}$ \\
\hline Dale \& Wilson & 1978 & $\begin{array}{l}\text { A comparison of leaf and ear development in barley cultivars as affected by nitrogen } \\
\text { supply. }\end{array}$ \\
\hline Gallagher \& Biscoe & 1978 & Radiation absorption, growth and yield of cereals. \\
\hline Gregory et al. & $1978 a$ & Water relations in winter wheat: 2 . Soil water relations. \\
\hline Gregory et al. & $1978 b$ & Water relations of winter wheat: 1 . Growth of the root system. \\
\hline Legg et al. & 1979 & $\begin{array}{l}\text { The effects of drought on barley growth: Models and measurements showing the relative } \\
\text { importance of leaf area and photosynthetic rate. }\end{array}$ \\
\hline Gregory et al. & 1981 & $\begin{array}{l}\text { Nutrient relations in winter wheat. } 3 \text {. Nitrogen uptake, photosynthesis of flag leaves and } \\
\text { translocation of nitrogen to grain. }\end{array}$ \\
\hline Austin & 1982 & Crop characteristics and the potential yield of wheat. \\
\hline Barraclough & 1984 & $\begin{array}{l}\text { The growth and activity of winter wheat roots in the field: Root growth of high-yielding } \\
\text { crops in relation to shoot growth. }\end{array}$ \\
\hline Gregory et al. & 1984 & Effects of fertilizer on root growth and water use of barley in northern Syria. \\
\hline McGowan et al. & 1984 & $\begin{array}{l}\text { Water relations of winter wheat. } 5 \text { : The root system and osmotic adjustment in relation to } \\
\text { crop evaporation. }\end{array}$ \\
\hline Singh et al. & 1984 & Physiological maturity in Aestivum wheat: visual determination. \\
\hline Fischer & 1985 & Number of kernels in wheat crops and the influence of solar radiation and temperature. \\
\hline Kirby et al. & 1987 & $\begin{array}{l}\text { An analysis of primordium initiation in Avalon winter wheat crops with different sowing } \\
\text { dates and at nine sites in England and Scotland. }\end{array}$ \\
\hline Porter et al. & 1987 & $\begin{array}{l}\text { An analysis of morphological development stages in Avalon winter wheat crops with dif- } \\
\text { ferent sowing dates and at ten sites in England and Scotland. }\end{array}$ \\
\hline Thorne \& Wood & 1988 & Contributions of shoot categories to growth and yield of winter wheat. \\
\hline Kirby & 1992 & $\begin{array}{l}\text { A field study of the number of main shoot leaves in wheat in relation to vernalization and } \\
\text { photoperiod. }\end{array}$ \\
\hline Cousens et al. & 1993 & $\begin{array}{l}\text { Comparative rates of emergence and leaf appearance in wild oats (Avena fatua), winter } \\
\text { barley (Hordeum sativum), and winter wheat (Triticum aestivum). }\end{array}$ \\
\hline Kirby et al. & 1994 & $\begin{array}{l}\text { Coordination of stem elongation and Zadoks growth stages with leaf emergence in wheat } \\
\text { and barley. }\end{array}$ \\
\hline Kernich et al. & 1995 & Barley development as affected by rate of change of photoperiod. \\
\hline Moot et al. & 1996 & Rate of change in harvest index during grain-filling of wheat. \\
\hline Slafer & 1996 & $\begin{array}{l}\text { Differences in phasic development rate amongst wheat cultivars independent of responses } \\
\text { to photoperiod and vernalization. A viewpont of the intrinsic earliness hypothesis. }\end{array}$ \\
\hline Mulholland et al. & 1997 & $\begin{array}{l}\text { Timing of critical developmental stages and leaf production in field-grown spring wheat } \\
\text { for use in crop models. }\end{array}$ \\
\hline Gillett et al. & 2001 & $\begin{array}{l}\text { An approach to modelling the effect of environmental and physiological factors upon } \\
\text { biomass accumulation in winter wheat. }\end{array}$ \\
\hline Smith et al. & 2002 & EuroSOMNET - a European database of long-term experiments on soil organic matter. \\
\hline \multicolumn{3}{|l|}{ Modelling studies } \\
\hline Barnes et al. & 1976 & $\begin{array}{l}\text { A dynamic model for the effects of potassium and nitrogen fertilizers on the growth and } \\
\text { nutrient uptake of crops. }\end{array}$ \\
\hline Greenwood \& Barnes & 1978 & A theoretical model for the decline in the protein content in plants during growth. \\
\hline Thompson & 1981 & Modelling the field drying of hay. \\
\hline Towner & 1983 & $\begin{array}{l}\text { A theoretical examination of Burns' (1975) equation for predicting the leaching of nitrate } \\
\text { fertilizer applied to a soil surface. }\end{array}$ \\
\hline Porter & 1984 & A model of canopy development in winter wheat. \\
\hline Weir et al. & 1984 & A winter wheat crop simulation model without water or nutrient limitations. \\
\hline Addiscott \& Whitmore & 1987 & $\begin{array}{l}\text { Computer simulation of changes in soil mineral nitrogen and crop nitrogen during } \\
\text { autumn, winter and spring }\end{array}$ \\
\hline Travis & 1987 & $\begin{array}{l}\text { Use of a simple model to study factors affecting the size distribution of tubers in potato } \\
\text { crops. }\end{array}$ \\
\hline Pal et al. & 1990 & $\begin{array}{l}\text { Simple water-balance models for simulating moisture, salinity, and sodicity profiles in soil } \\
\text { under wheat. }\end{array}$ \\
\hline
\end{tabular}


Table 1 (cont.)

\begin{tabular}{|c|c|c|}
\hline Author & Year & Title \\
\hline Firman et al. & 1992 & Predicting the emergence date of potato sprouts \\
\hline McMaster et al. & 1992 & Simulating winter wheat shoot apex phenology. \\
\hline Bradbury et al. & 1993 & $\begin{array}{l}\text { Modelling the fate of nitrogen in crop and soil in the years following application of } \\
{ }^{15} \mathrm{~N} \text {-labelled fertilizer to winter wheat. }\end{array}$ \\
\hline Kocabas et al. & 1993 & $\begin{array}{l}\text { Sensitivity analyses of the ARCWHEAT } 1 \text { crop model: The effects of changes in radiation } \\
\text { and temperature. }\end{array}$ \\
\hline Benbi & 1994 & Prediction of leaf area indices and yield of wheat. \\
\hline Hamer et al. & $1994 a$ & $\begin{array}{l}\text { Crop production and water-use. II. The development and validation of a water-use model } \\
\text { for sugarbeet. }\end{array}$ \\
\hline Hamer et al. & $1994 b$ & $\begin{array}{l}\text { Crop production and water-use. III. The development and validation of a water-use model } \\
\text { for potato. }\end{array}$ \\
\hline Siddons et al. & 1994 & $\begin{array}{l}\text { The use of a land suitability model to predict where autumn-sown, determinate genotypes } \\
\text { of the white lupin (Lupinus albus) might be grown in England and Wales. }\end{array}$ \\
\hline Wright et al. & 1994 & $\begin{array}{l}\text { Crop production and water-use. I. A model for estimating crop water-use with limited } \\
\text { data. }\end{array}$ \\
\hline $\begin{array}{l}\text { Brignall \& } \\
\text { Rownsevell }\end{array}$ & 1995 & $\begin{array}{l}\text { Land evaluation modelling to assess the effects of climate change on winter wheat potential } \\
\text { in England and Wales. }\end{array}$ \\
\hline Craigon et al. & 1995 & Modelling the effects of vernalization on progress to final leaf appearance in winter wheat. \\
\hline Hamer & 1995 & $\begin{array}{l}\text { Modelling the effects of sowing date and plant density on the yield and timing of devel- } \\
\text { opment of Brussels sprouts (Brassica oleracea). }\end{array}$ \\
\hline Cao \& Moss & 1997 & $\begin{array}{l}\text { Modelling phasic developments in wheat: a conceptual integration of physiological com- } \\
\text { ponents. }\end{array}$ \\
\hline Kirby \& Wrightman & 1997 & Discrepancies between observed and predicted growth stages in wheat. \\
\hline Weightman et al. & 1997 & Prediction of leaf and internode development in wheat. \\
\hline Wright et al. & 1997 & Crop production and water-use. IV. Yield function for sugar beet. \\
\hline Phillips et al. & 1998 & $\begin{array}{l}\text { A basis for predictive modelling of the relationship of the potato yield to population } \\
\text { density of potato cyst nematode, Globodera pallida. }\end{array}$ \\
\hline Kaur \& Hundal & 1999 & $\begin{array}{l}\text { Forecasting growth and yield of groundnut (Arachis hypogaea) with a dynamic simulation } \\
\text { model 'PNUTGROW' under Punjab conditions }\end{array}$ \\
\hline Keady et al. & 2000 & $\begin{array}{l}\text { Prediction of silage feeding value from the analysis of the herbage at ensiling and effects of } \\
\text { nitrogen fertilizer, date of harvest and additive treatment on grass silage composition. }\end{array}$ \\
\hline Kebreab et al. & 2000 & $\begin{array}{l}\text { An evaluation of uptake and developmental impact in the semi-arid tropics of four crop } \\
\text { production models. }\end{array}$ \\
\hline Wurr et al. & 2000 & $\begin{array}{l}\text { Climate change, a response surface study of the effects of } \mathrm{CO}_{2} \text { and temperature on the } \\
\text { growth of French beans. }\end{array}$ \\
\hline Cheyglinted et al. & 2001 & Assessment of the CERES-rice model for rice production in the central plain of Thailand. \\
\hline Gabrielle et al. & 2001 & $\begin{array}{l}\text { Ability of the SUNDIAL model to simulate the short-term dynamics of }{ }^{15} \mathrm{~N} \text { applied to } \\
\text { winter wheat and oilseed rape. }\end{array}$ \\
\hline Ntare et al. & 2001 & $\begin{array}{l}\text { Evaluation of groundnut genotypes for heat tolerance under field conditions in a Sahelian } \\
\text { environment using a simple physiological model for yield. }\end{array}$ \\
\hline Kage et al. & 2003 & $\begin{array}{l}\text { Aspects of nitrogen use efficiency of cauliflower I. A simulation modelling based analysis of } \\
\text { nitrogen availability under field conditions. }\end{array}$ \\
\hline Lombnaes \& Singh & 2003 & $\begin{array}{l}\text { Predicting } \mathrm{Zn} \text { and } \mathrm{Cu} \text { status in cereals - potential for a multiple regression model using soil } \\
\text { parameters. }\end{array}$ \\
\hline McMaster \& Wilhelm & 2003 & $\begin{array}{l}\text { Phenological responses of wheat and barley to water \& temperature: improving simulation } \\
\text { models. }\end{array}$ \\
\hline Zahedi \& Jenner & 2003 & $\begin{array}{l}\text { Analysis of effects in wheat of high temperature on grain filling attributes estimated from } \\
\text { mathematical models of grain filling. }\end{array}$ \\
\hline Nain et al. & 2004 & $\begin{array}{l}\text { Use of CERES-wheat model for wheat yield forecast in central Indo-Gangetic Plains of } \\
\text { India. }\end{array}$ \\
\hline Holst & 2005 & $\begin{array}{l}\text { Recursive density equivalents: An improved method for forecasting yield loss caused by } \\
\text { mixed weed populations. }\end{array}$ \\
\hline
\end{tabular}

there may be fewer potential difficulties associated with input data to crop simulation models, care must still be exercised in order to avoid problems. The objective of the present paper is to discuss many of the potential errors associated with field observations, input data and simulation algorithms. These potential errors are presented with examples from personal experience and the literature. The present authors' 
purpose is not to give detailed methods for avoiding these errors (likely an impossible task because solutions are situation specific), but rather to alert the modelling community how seemingly logical and benign assumptions can spawn misleading, and sometimes embarrassing, conclusions and outcomes. To rephrase a quote attributed to the late US Senator Everett Dirksen when discussing budget concerns ('a billion here, a billion there and pretty soon you are talking about real money'), substitute 'error' in the appropriate places in the above statement and the result could be a relatively large error.

\section{FIELD OBSERVATIONS}

The ability to simulate plant development is an important component of any crop simulation model because different growth processes occur at different times in the development of a plant. Measurements of plant development present a series of challenges, in part because of their subjective nature; they may differ from observer to observer. Scales to compare nondestructive field observations with defined stages of plant development help minimize this subjectivity. Scales have been created by Feekes (Large 1954) and Zadoks et al. (1974) for cereal crops. Similarly, scales for maize and soybean (Glycine max (L.) Merr.) have been prepared by Ritchie et al. $(1997 a, b)$. In cereal crops, stages such as single and double ridge require destructive sampling and observation under a powerful hand lens. Although physiological maturity is clearly defined in the Zadoks scale, as when a thumbnail can no longer dent a kernel, this measure is not often used when there are many plots to evaluate because of time considerations in sampling many plants. Hanft \& Wych (1982) evaluated 13 methods to determine physiological maturity and found the most practical method to be the complete loss of green colour from the glumes of the lower spikelets. On the other hand, leaf appearance rate determined by the Haun stage (Haun 1973) is less subjective than determining development stages because actual measurements of leaf length can be used to compute this stage.

Measurements of plant development should be made every $2-3$ days, but are frequently made at intervals of 7-14 days. In addition, to conserve space in published reports, development stages are reported at less frequent intervals or in figures that may be difficult to accurately interpret. Under certain meteorological conditions, it may be possible for plants to stay at the same stage of development for extended periods. The present authors have observed this situation in wheat (Triticum aestivum L.) where the plants remained at the single ridge stage for about 10 days.

Grain yield on a land area basis can be determined either by machine or hand harvesting; each
Table 2. Yield estimate for combine and hand
harvested plots

\begin{tabular}{cccr}
\hline \hline & & \multicolumn{2}{c}{ Yield (t/ha) } \\
\cline { 3 - 4 } Hybrid & $\begin{array}{c}\text { Nitrogen rate } \\
(\mathrm{kg} \mathrm{N} / \mathrm{ha})\end{array}$ & Combine & Hand \\
\hline P3394 & 0 & $6 \cdot 38$ & $7 \cdot 20$ \\
& 70 & $8 \cdot 19$ & $9 \cdot 77$ \\
& 140 & $8 \cdot 57$ & $11 \cdot 15$ \\
Mean & 210 & $9 \cdot 57$ & $12 \cdot 14$ \\
P33A14 & & $8 \cdot 18$ & $10 \cdot 06$ \\
& 0 & $7 \cdot 22$ & $8 \cdot 05$ \\
& 140 & $9 \cdot 09$ & $11 \cdot 34$ \\
Mean & 210 & $10 \cdot 29$ & $13 \cdot 23$ \\
& & $11 \cdot 14$ & $13 \cdot 65$ \\
\hline \hline
\end{tabular}

method has advantages and disadvantages. Machine harvesting allows the entire plot or large area to be sampled, minimizing any concerns about plantto-plant differences within the plot. There are losses, however, associated with machine harvesting. On a well-maintained combine with a skilled operator, one can assume a proportional yield loss of 0.03 for wheat (Anonymous 2003) but a $0 \cdot 05-0 \cdot 10$ loss for sorghum (Sorghum bicolor (L.) Moench; Donald \& Ogburn 1982) and as high as $0 \cdot 30-0 \cdot 50$ for machine harvested amaranth (Amaranthus spp. Amaranthaceae; Fitterer et al. 1996). On combines that are not well maintained or not operated skillfully, losses can be much greater. Crop simulation models report simulated yield with no assumption of harvest losses.

Hand harvesting eliminates some of these problems, but substitutes other problems: the need to select a representative sample and large enough sample size. Hand harvesting is a time-consuming process, which requires a disciplined labour force. Errors associated with loss of grain or measurement of sample area can also occur with hand harvest methods. Hand harvesting allows determination of the mass of individual plant components (leaves, sheaths, stems and reproductive organs) and leaf area index.

To further exacerbate the problem, if both machine and hand harvest are conducted, results seldom agree though they should be highly correlated. A subset of data from an $\mathrm{N}$ response study conducted to determine the impact of several controlled-release formulations of $\mathrm{N}$ fertilizer on maize grain yield in the Central Platte Valley of Nebraska, illustrates this problem (Table 2). Mean yield estimates for both hybrids were about $2 \mathrm{t} /$ ha greater with hand harvesting than with machine harvesting. Even though additional $\mathrm{N}$ increased yield, differences between the harvest methods remained. In fact, standard errors, F-values, and probabilities of a greater $\mathrm{F}$ for hybrid, 
$\mathrm{N}$ rate, and their interaction were similar for the two harvest methods (data not shown). Combine and hand harvest yield data were highly correlated ( $r=$ $0 \cdot 81, n=96)$. The conclusion about the effects of treatments would be similar for both harvest methods; only the absolute estimates of grain yield differed. If these observed yield values were compared to simulated values, which set of observed values should be used in this comparison?

Mean kernel mass ( $\mathrm{mg} / \mathrm{kernel})$ is usually based on the mass of some specified or known number of kernels (usually 200-1000). Dividing mean kernel mass into yield provides one estimate of the mean kernel number per unit area. Care must be exercised in using this approach to ensure that the moisture content of the kernel is taken into account, as well as the moisture content of the grain yield estimates. Depending on storage conditions and time between measurement of grain yield and kernel mass, the moisture content difference can be substantial. Simulated values of mass are usually based on a zero moisture content, but field data are usually adjusted to grain marketing standards, i.e. a water content of $155 \mathrm{~g} / \mathrm{kg}$ for maize, based on estimates of field moisture content that can be determined in several ways (oven drying, moisture meter, etc.) with several sources of error associated with each method. Most newer research combines are equipped with automated scale and moisture meter systems; for accurate readings these metered systems obviously must be well maintained and calibrated. (Proper maintenance and calibration applies to all sensors, which again is obvious, but should be restated.) Even under optimum conditions the grain will never dry to zero moisture, but perhaps to $30 \mathrm{~g} /$ $\mathrm{kg}$ for wheat, then a grain moisture meter can be used to estimate the correction necessary to bring the mass to the equivalent of zero moisture, again assuming the meter is accurately calibrated.

The above measurement methodologies are appropriate given that most crop simulation models predict mean kernel number and mean kernel mass. These mean values would probably differ from values determined by direct, individual measurements. Furthermore, if one determined the individual components of yield from plot samples (for wheat; plants per unit area, culms per plant, kernels per culm, and individual kernel mass) and multiplied them together; the result may not equal the machine-harvested yield due to variability. Thus, there can be two 'correct' answers regarding yield components.

Kernel moisture also plays an important role in determining component content, such as protein content of the grain, which is usually estimated as the ratio of the kernel nitrogen mass divided by the kernel mass, and the resulting quantity multiplied by a constant $(5 \cdot 7)$. In this case, the greater the moisture content of the grain, the lower the protein content since the kernel mass is in the denominator of this ratio. If appropriate corrections for grain water content are not made, observed and simulated results should disagree. A similar argument can be made for oil content of grain or seed. Again, depending upon the question being asked the disagreement will either be trivial or significant.

Moisture is also an important factor when considering radiation (or light) use efficiency, defined as the amount of dry matter formed (above ground or total) per unit of radiation (solar or PAR) absorbed (or intercepted) for a defined time interval. As with all dry matter sampling, care must be exercised to minimize or eliminate loss of sample mass during processing. Leaves and flower parts dry more rapidly than stems and are easy to lose as samples or sample bags are moved, handled and weighed. When using published values of yield and yield components in order to evaluate a crop simulation model, it is important to take into account the moisture content of these values in the comparisons. Field sampling losses are not reported in most cases.

Harvest index (HI), the ratio of grain yield to total above-ground biomass, is frequently used to determine grain yield from simulated total above-ground biomass. Harvest index is also frequently reported for field experiments. Although the definition and computation of $\mathrm{HI}$ is straightforward, errors may arise in its calculation. If grain is reported at $155 \mathrm{~g}$ water $/ \mathrm{kg}$, and total above-ground biomass is reported as dry matter, the resulting estimate of $\mathrm{HI}$ based on field measurements will be greater than a simulated value. If $\mathrm{HI}$ is computed from values in tables and text of published papers, grain and total above-ground biomass may not have been sampled at the same time, introducing a similar type of error, that is, numerator and denominator are at different moisture contents. Ideally, measurements of grain and above-ground dry matter should be done at the same time, but they may not be. To wait until the grain is dry enough to harvest means that above-ground components may be lost. On the other hand, if one harvests at physiological maturity, when above-ground biomass is at a maximum, the moisture content of the grain is too high for efficient mechanical harvesting. There is a high probability that harvesting at this time would result in much grain loss. In variety trials there would be an argument for harvesting each variety when it becomes mature (to mimic what a grower would do) rather than harvest all varieties at the same time. In addition to the above, one has to consider hand versus machine harvesting and the impact of the different cutting heights associated with each method, on estimates of plant biomass. Frequently hand harvested material is cut near ground level in order to permit later measurement and analysis of plant components. If plant dry mass from machine harvest procedures is used, it may underestimate the allocation to above-ground biomass, which 
will affect the computation of harvest index. Using a field-determined value or a published derived value of $\mathrm{HI}$ as a component of a simulation model may introduce errors in the simulated yield.

Results of yield trials of different genotypes can be a good source of data to evaluate crop simulation models. While a data set based on yield trials may contain sowing, anthesis, and dates of physiological maturity and yield components, it usually does not contain plant population density (plants $/ \mathrm{m}^{2}$ ). Plant population density is an important input parameter for many crop simulation models and can be estimated by dividing the seeding rate $\left(\mathrm{g} / \mathrm{m}^{2}\right)$ by the kernel dry mass $(\mathrm{mg})$ and assuming some fraction of the seeds germinated and emerged. Unfortunately, this calculation combines several assumptions; that the seeding rate was known and accurately reported and was uniform across genotypes, that kernel mass (which is usually not reported) was accurately estimated, and that the fraction of seeds germinating, emerging, and surviving to maturity were estimated with accuracy.

\section{INPUT DATA}

Automated weather stations (which usually measure air temperature, solar radiation, precipitation, relative humidity, wind speed, wind direction, and other parameters) are an essential source of data for crop simulation models. Maintenance of sensors may not be possible on a frequent basis because of the time to travel to a site and problems with sensors are usually identified using quality control techniques. In addition, sensors may have limitations that only become apparent under extreme conditions, such as the non-linearity of the tipping rate of tipping bucket rain gauges and rainfall intensity when, under high rainfall conditions, the bucket cannot tip fast enough to capture all rainfall during intense events. In a simulation study, Heinemann et al. (2002) showed that negatively biased precipitation values, i.e. values less than the mean observed values, from tipping bucket rain gauges reduced simulated yields for four crops (maize, wheat, soybean and peanut (Arachis hypogaea (L.)), soybean having the largest decrease $(19 \%)$ in simulated yield and wheat the least, in fact showing a very slight increase $(0 \cdot 2 \%)$. Yield responses were more sensitive to negative rather than positive biased precipitation values. Data for the Heinemann et al. (2002) study came from Tifton, Georgia, USA, which has an annual mean total precipitation of $1122 \mathrm{~mm}$. For regions with half of this amount of precipitation, errors in rain gauge measurements would probably amplify these results. The message from that study, as well as the other studies cited in the present paper, is to be sensitive to potential sensor errors when analysing simulation model output data.
Aggarwal (1995) studied the outputs of a crop simulation model based on uncertainties in crop, weather and soil inputs represented by statistical distributions of the input parameters. 'Uncertainties' in the outputs increased as the environments changed from one limited only by temperature and radiation (potential), to an irrigated environment, to one limited by water and nitrogen (rainfed). The resulting bias from the first two environments was similar. A way to deal with the uncertainties of the output data associated with input data uncertainties was to have fixed soil and crop inputs run with a long series of weather data. Variables associated with simulating photosynthesis and leaf area were important in the first two systems, and soil nitrogen and vapour pressure inputs were important in the irrigated system. In the rainfed system, soil and weather inputs were more important than crop inputs.

Soil name and classification are often reported in the literature for field sites based solely on location and defined soil series from published data (i.e. soil survey reports), rather than from field measurements. Modellers must assume the soil at the site meets the mean characteristics for the soil, when in fact the soil may only marginally meet the classification criteria for the stated soil and therefore have different characteristics (e.g. pH, particle size distribution, organic matter content, etc.) than a soil meeting the central trend of the stated soil. Individually these differences may have a small influence on the simulated output, but taken together their impact may be relatively large.

Gijsman et al. (2003) examined the use of eight algorithms to generate values for drained upper limit (DUP) and lower limit (LL) of plant-available water (values widely used in crop simulation models to define the amount or volume of water held in the soil that can be extracted by plants). These values can be determined experimentally, but the procedures are time consuming and tedious. In addition, empirical determinations require direct access to soils under investigation. In many simulation studies, investigators do not have access to the soil, or the soil under the conditions, in question. In these circumstances, derivation of DUL and LL may be the only reasonable alternative. Unfortunately, the thorough sensitivity analysis performed by Gijsman et al. (2003) indicated that none of the methods for computing DUL and LL from the more readily available soil texture data, proved acceptable over the entire range of textural classes. However, the method described in Saxton et al. (1986) performed the best of the methods investigated in this study, except for very sandy soils where no model performed well. Additionally, Gijsman et al. (2003) highlight what they call a "worrisome lack of accuracy in presentation of methods in articles'. They continue, stating: 'This means that among the many methods available 
Table 3. Length of record, elevation, mean annual daily minimum and maximum temperatures, and mean annual total precipitation for Astoria, Oregon and Bishop, California, USA

\begin{tabular}{lcccc}
\hline \hline $\begin{array}{c}\text { Location and } \\
\text { length of record }\end{array}$ & $\begin{array}{c}\text { Elevation } \\
(\mathrm{m})\end{array}$ & $\begin{array}{c}\text { Mean annual daily } \\
\text { minimum temperature }\left({ }^{\circ} \mathrm{C}\right)\end{array}$ & $\begin{array}{c}\text { Mean annual daily } \\
\text { maximum temperature }\left({ }^{\circ} \mathrm{C}\right)\end{array}$ & $\begin{array}{c}\text { Mean annual total } \\
\text { precipitation }(\mathrm{mm})\end{array}$ \\
\hline $\begin{array}{c}\text { Astoria } \\
(1997-2002)\end{array}$ & $2 \cdot 7$ & $7 \cdot 1$ & $14 \cdot 8$ & $1820 \cdot 4$ \\
$\begin{array}{c}\text { Bishop } \\
(1997-2002)\end{array}$ & $1252 \cdot 4$ & $3 \cdot 0$ & $23 \cdot 6$ & $108 \cdot 3$ \\
\hline \hline
\end{tabular}

Table 4. Monthly root mean square error of the daily mean temperature for Astoria, Oregon, USA, using three methods to determine the daily mean temperature. More details about these procedures are given in Weiss \& Hays (2005)

\begin{tabular}{lccc}
\hline \hline & \multicolumn{3}{c}{$\begin{array}{c}\text { Root mean square error } \\
\text { for daily mean temperature }\end{array}$} \\
\cline { 2 - 4 } Month & $\begin{array}{c}\text { Max/Min } \\
\left({ }^{\circ} \mathrm{C}\right)\end{array}$ & $\begin{array}{c}\text { Weighted } \\
\left({ }^{\circ} \mathrm{C}\right)\end{array}$ & $\begin{array}{c}\text { CERES } \\
\left({ }^{\circ} \mathrm{C}\right)\end{array}$ \\
\hline Jan & 0.63 & 0.67 & 0.63 \\
Feb & 0.60 & 0.66 & 0.61 \\
Mar & 0.54 & 0.62 & 0.54 \\
Apr & 0.63 & 0.49 & 0.64 \\
May & 0.56 & 0.51 & 0.57 \\
Jun & 0.51 & 0.43 & 0.52 \\
Jul & 0.62 & 0.41 & 0.64 \\
Aug & 0.61 & 0.43 & 0.64 \\
Sep & 0.82 & 0.60 & 0.86 \\
Oct & 0.69 & 0.65 & 0.70 \\
Nov & 0.72 & 0.67 & 0.73 \\
Dec & 0.61 & 0.57 & 0.61 \\
\hline \hline
\end{tabular}

it is very difficult to identify how exactly the specific method was meant to be applied.'

\section{ALGORITHMS}

Minimum and maximum air temperatures are important input parameters into many crop simulation models. Often these temperatures are used in nonlinear algorithms. A question that should be addressed in the development of a non-linear algorithm is whether the temperatures be averaged first to form a single daily mean value and then the response calculated or should the response be calculated for each temperature and then averaged in a sequential manner? Weiss \& Hays (2005) evaluated five different methods to calculate daily mean air temperature (Appendix 1) and used these different temperature methods in a non-linear algorithm of plant development based on Streck et al. (2003; Appendix 2). This non-linear algorithm was evaluated over a wide range of locations; elevation, temperature and precipitation
Table 5. Monthly root mean square error of the daily mean temperature for Bishop, California, USA, using three methods to determine the daily mean temperature. More details about these procedures are given in Weiss \& Hays (2005)

\begin{tabular}{lccc}
\hline \hline & \multicolumn{3}{c}{$\begin{array}{c}\text { Root mean square error } \\
\text { for daily mean temperature }\end{array}$} \\
\cline { 2 - 4 } Month & $\begin{array}{c}\text { Max/min } \\
\left({ }^{\circ} \mathrm{C}\right)\end{array}$ & $\begin{array}{c}\text { Weighted } \\
\left({ }^{\circ} \mathrm{C}\right)\end{array}$ & $\begin{array}{c}\text { CERES } \\
\left({ }^{\circ} \mathrm{C}\right)\end{array}$ \\
\hline Jan & 1.07 & 1.02 & 1.16 \\
Feb & 0.84 & 0.87 & 0.87 \\
Mar & 1.06 & 0.92 & 0.96 \\
Apr & 1.23 & 1.11 & 1.07 \\
May & 1.59 & 1.22 & 1.41 \\
Jun & 1.72 & 1.25 & 1.53 \\
Jul & 1.88 & 1.28 & 1.68 \\
Aug & 1.61 & 1.21 & 1.40 \\
Sep & 1.21 & 1.06 & 1.05 \\
Oct & 0.87 & 1.00 & 0.86 \\
Nov & 0.97 & 1.15 & 1.03 \\
Dec & 1.09 & 0.94 & 1.22 \\
\hline \hline
\end{tabular}

data for the two extreme locations, Astoria, Oregon, USA and Bishop, California, USA are given in Table 3. There was little difference in the daily mean air temperatures calculated by the different methods as evaluated by the root mean square error (RMSE) (Tables 4 and 5). The differences in magnitude of the RMSE indicate the variability of the two climates at these locations. For example, the July RMSE value for the $\mathrm{max} / \mathrm{min}$ method was $0.62{ }^{\circ} \mathrm{C}$ for Astoria and $1.88^{\circ} \mathrm{C}$ for Bishop. The empirical coefficient in this non-linear algorithm of plant development, the maximum development rate, was determined based on the daily mean air temperature of the 24-hourly temperature values. There were differences in the phenological responses from the non-linear algorithm when using any sequential approach when compared with the original algorithm (Table 6). For Astoria, the differences in the simulated days between the original algorithm and any sequential method to reach a specific stage were between 0.5 to 2.2 days. Even though the calculation methods from the original algorithm 
Table 6. The mean differences in days between simulated phenological development using different temperature methods. More details about these methods are given in Weiss \& Hays (2005)

\begin{tabular}{lcc}
\hline \hline & $\begin{array}{c}\text { Astoria, } \\
\text { Oregon, } \\
\text { USA (days) }\end{array}$ & $\begin{array}{c}\text { Bishop, } \\
\text { California, } \\
\text { USA (days) }\end{array}$ \\
\hline Sequential hourly & $1 \cdot 0$ & $9 \cdot 3$ \\
Sequential max/min & $2 \cdot 2$ & $39 \cdot 8$ \\
Sequential weighted & $0 \cdot 5$ & $4 \cdot 8$ \\
Sequential mean 3 hour & $0 \cdot 8$ & $9 \cdot 0$ \\
Sequential CERES & $0 \cdot 7$ & $12 \cdot 5$ \\
Max/min & $-0 \cdot 3$ & $1 \cdot 8$ \\
Weighted & $0 \cdot 2$ & $-0 \cdot 7$ \\
Mean 3 hour & $0 \cdot 0$ & $0 \cdot 0$ \\
CERES & $-0 \cdot 5$ & $1 \cdot 2$ \\
\hline \hline
\end{tabular}

were not followed, the simulated results were very good. This result implies that any calculation method works reasonably well in a relatively uniform climate, which implies that the 'correct' answer is obtained for the wrong reasons. On the other hand, for the more extreme climate found in Bishop, the differences between the simulated days to reach a specific stage were between 4.8 and 39.8 days. Not following the procedures in the original algorithm resulted in poor simulations for this type of climate. For either location, using a single mean temperature resulted in simulations that differed by 0.5 to 1.8 days. These results do not imply that the sequential approaches are inappropriate; just that the mean temperature method used to determine empirical coefficients in a non-linear algorithm must be consistently used in all applications especially in development of model algorithms and comparison with observed data for model evaluation. Although a specific parameter was used in Weiss \& Hays (2005), the results are relevant to any non-linear algorithm containing empirically determined coefficients.

In simulating the developmental response of photosensitive plants, the ability to predict daylength is essential. Daylength can be defined in six ways depending upon the angle of the sun with the horizon (Forsythe et al. 1995). The US government definition of sunrise and sunset is when the rim of the sun is $0.8333^{\circ}$ below the horizon. The value of $0.8333 \mathrm{de}-$ grees is a combination of the radius of the sun (in degrees as seen from the earth) plus 34 minutes for the value adopted for the refraction of light through the atmosphere. Daylength based on civil, nautical, and astronomical twilight occurs when the sun is higher than 6,12 and $18^{\circ}$ below the horizon, respectively. Many modellers assume photosensitive plants respond to light beginning at civil twilight. To further complicate this issue, it is likely that species have different minimum thresholds for photosensitive responses. The CROPGRO model (Boote et al. 1998) uses a definition of daylength based on 0 degrees, i.e. when the sun is on the horizon. The difference in daylength between this definition and civil twilight is about $1 \mathrm{~h}$ at $41^{\circ}$ latitude. This difference in daylength depends upon the location of the sun and the horizon; 0 and $6^{\circ}$ below the horizon may influence the simulation of development in CROPGRO. Forsythe et al. (1995) found that the solar declination algorithm in CERES-Wheat (Jones \& Kiniry 1986) was in error, which could result in varying errors in the computation of daylength depending upon latitude and day of year ranging from no error at the equator to $170 \mathrm{~min}$ at $60^{\circ} \mathrm{N}$ latitude between day of year 148-201 (28 May-20 July). When Forsythe et al. (1995) corrected for this error in CERES-Wheat, they found that the simulated time to terminal spikelet varied by one week between the US government definition of daylength and civil twilight. These differences in calculated daylength may not be as serious as anticipated since these values are multiplied by empirical coefficients to simulate the duration of a developmental phase, the value of the empirical coefficient compensating for the problem associated with the calculation of daylength. This calculation, involving compensating errors, is probably valid if the empirical coefficients and the calculated daylength are based on the same observational data set. Differences in the choice and application of daylength algorithms may produce widely differing results, paralleling the confusion in application of the algorithm for thermal time highlighted by McMaster \& Wilhelm (1997).

The above discussion is based upon the assumption that the topography is uniform with no nearby obstructions. For conditions of non-uniform topography, the definitions of sunrise and sunset would have to be adjusted for each unique situation. That is, traditional definitions of sunrise and sunset, and therefore daylength, should be adjusted for sites in mountainous areas.

In addition to the different definitions of daylength that can be used, there are different types of algorithms that can be used to simulate a photoperiod response, Fig. 1. One response is based on two straight lines, which is used in SOYGRO (Boote et al. 1998). A negative exponential relationship can also be used to describe the relationship between photoperiod and a 0-1 response (Angus et al. 1981). Both relationships require two inputs, a critical photoperiod, which in the case of short day plants is the length of daylight above which there is no response. In Fig. 1, the critical photoperiod is about $17 \mathrm{~h}$. The second parameter is a shape factor, which in the case of the two straight lines relationship is the slope of the line that intersects the $\mathrm{x}$-axis. A similar definition of the shape factor applies to the negative exponential relationship, how rapidly the response decreases with 


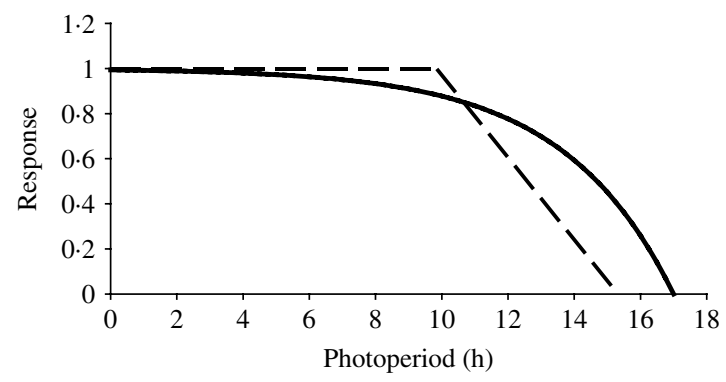

Fig. 1. Comparison of photoperiod response functions (0-1) based on two straight lines (dashed lines) and a continuous curve (solid line).

increasing photoperiod in a non-linear fashion. As photoperiod increases the differences in response between the two relationships increase until it is about 0.20 at $11 \mathrm{~h}$, the straight line relationship with a value of $1 \cdot 00$, while the negative exponential approach has a value of $0 \cdot 80$. At about $13 \mathrm{~h}$, the negative exponential relationship begins to over-predict compared with the straight-line relationship. Results from these two relationships are used with empirically determined coefficients to provide reasonable responses, although the negative exponential relationship was based on field measurements.

\section{CONCLUSIONS}

The intent of the present paper was not to serve as a guide on avoiding errors, but rather to stimulate thinking and discussion of the types of potential errors (variation may be a better term) that can complicate our attempts to develop, construct, evaluate, and use crop simulation models and determine how accurately they describe responses observed in the field. Each of these steps has the potential to cause disagreement between observed and simulated values. The present authors' hope is that the current paper highlights enough examples so that those using models think broadly about causes for agreement or disagreement between field observation and simulation results. We realize that the thoughts expressed in this paper are not completely original. No doubt others have thought of at least some of these examples; they may even have additional examples; they may even have better examples. Listing examples of how observed and simulated data may disagree is easy. Finding ways to avoid or compensate for the limitation of both field observations and simulation results is the difficult and an ongoing challenge. We have purposely avoided providing suggested solutions for the examples given in this paper. Solutions are situation- and objective-specific. As one goes from generalities to specifics, that well-worn phrase, the devil is in the details, is applicable.

As the Journal of Agricultural Science, Cambridge enters its second century of publishing, crop simulation models will be increasingly used at all levels to organize and understand the relationships between physical, chemical and biological processes, genetics, and management practices in crop production. We anticipate that the Journal of Agricultural Science, Cambridge will remain a primary outlet for these types of papers. Thorough reporting by authors, assessment and comment by reviewers, and oversight by editors will greatly help in clearly communicated objectives, methods and results. Together, these efforts will minimize the types of misunderstandings, misinterpretation and errors cited here.

A joint contribution of the University of Nebraska Agricultural Research Division and USDA-ARS, Lincoln, NE. Journal Series No. 14517. This research was supported in part by funds provided through the Hatch Act.

\section{REFERENCES}

Addiscott, T. M. \& Whitmore, A. P. (1987). Computer simulation of changes in soil mineral nitrogen and crop nitrogen during autumn, winter and spring. Journal of Agricultural Science, Cambridge 109, 141-157.

Aggarwal, P. K. (1995). Uncertainties in crop, soil and weather inputs used in growth models: Implications for simulated outputs and their applications. Agricultural Systems 48, 361-384.

Angus, J. F., Mackenzie, D. H., Morton, R. \& Schafer, C. A. (1981). Phasic development in field crops. II. Thermal and photoperiodic responses of spring wheat. Field Crops Research 4, 269-283.

Anonymous (2003). How to estimate grain harvest losses. Prairie Grains 54. Published online at http://www. smallgrains.org/springwh/June03/how/how.htm (verified 22/8/06).
Archer, C. B. (1980). Comments on 'Calculating the position of the sun'. Solar Energy 25, 91.

Austin, R. B. (1982). Crop characteristics and the potential yield of wheat. Journal of Agricultural Science, Cambridge 98, 447-453.

Baker, C. K., Gallagher, J. N. \& Monteith, J. L. (1980). Daylength change and leaf appearance in winter wheat. Plant, Cell and Environment 3, 285-287.

Barnes, A., Greenwood, D. J. \& Cleaver, T. J. (1976). A dynamic model for the effects of potassium and nitrogen fertilizers on the growth and nutrient uptake of crops. Journal of Agricultural Science, Cambridge 86, 225-244.

Barraclough, P. B. (1984). The growth and activity of winter wheat roots in the field: Root growth of highyielding crops in relation to shoot growth. Journal of Agricultural Science, Cambridge 103, 439-442. 
Bendi, D. K. (1994). Prediction of leaf area indices and yield of wheat. Journal of Agricultural Science, Cambridge 122, $13-20$.

BIFFEN, R. H. (1905). Mendel's laws of inheritance and wheat breeding. Journal of Agricultural Science, Cambridge 1, 4- 48.

Boote, K. J., Jones, J. W., Hoogenboom, G. \& Pickering, N. B. (1998). The CROPGRO model for grain legumes. In Understanding Options for Agricultural Production (Eds G. Y. Tsuji, G. Hoogenboom \& P. K. Thornton), pp. 99-128. Dordrecht, The Netherlands: Kluwer Academic Publishers.

Bradbury, N. J., Whitmore, A. P., Hart, P. B. S. \& JENKINSON, D.S. (1993). Modelling the fate of nitrogen in crop and soil in the years following application of ${ }^{15} \mathrm{~N}$ labelled fertilizer to winter wheat. Journal of Agricultural Science, Cambridge 121, 368-379.

Brignall, A. P. \& Rownsevell, M. D. A. (1995). Land evaluation modelling to assess the effects of climate change on winter wheat potential in England and Wales. Journal of Agricultural Science, Cambridge 124, 159-172.

CAO, W. \& Moss, D. N. (1997). Modelling phasic developments in wheat: a conceptual integration of physiological components. Journal of Agricultural Science, Cambridge 129, $163-172$

CARberry, P. S. (1991). Test of leaf-area development in CERES-Maize: a correction. Field Crops Research 27, $159-167$.

Cheyglinted, S., Ranamukhaarachchi, S. L. \& Singh, G. (2001). Assessment of the CERES-rice model for rice production in the central plain of Thailand. Journal of Agricultural Science, Cambridge 137, 289-298.

Cousens, R. D., Johnson, M. P., Weaver, S. E., Martin, T. D. \& Blair, A. M. (1993). Comparative rates of emergence and leaf appearance in wild oats (Avena fatua), winter barley (Hordeum sativum), and winter wheat (Triticum aestivum). Journal of Agricultural Science, Cambridge 118, 149-156.

Craigon, J., Atherton, J. G. \& Sweet, N. (1995). Modelling the effects of vernalization on progress to final leaf appearance in winter wheat. Journal of Agricultural Science, Cambridge 124, 369-377.

DAle, J. E. \& Wilson, R. G. (1978). A comparison of leaf and ear development in barley cultivars as affected by nitrogen supply. Journal of Agricultural Science, Cambridge 90, 503-508.

Donald, J. \& Ogburn, C. B. (1982). Harvesting, Drying and Storing Grain Sorghum. Circular ANR-243. Alabama, USA: Alabama Cooperative Extension System.

Firman, D. M., O'Brien, P. J. \& Allen, E. J. (1992). Predicting the emergence date of potato sprouts. Journal of Agricultural Science, Cambridge 118, 55-61.

Fischer, R. A. (1985). Number of kernels in wheat crops and the influence of solar radiation and temperature. Journal of Agricultural Science, Cambridge 105, 447-461.

Fitterer, S. A., Johnson, B. L. \& Schneiter, A. A. (1996). Grain amaranth harvest timeliness in eastern North Dakota. In Progress in New Crops (Ed. J. Janick), pp. 220-223. Alexandria, VA: ASHS Press.

Forsythe, W. C., Rykiel Jr., E. J., Stahl, R. S., Wu, H. \& Schoolfield, R. M. (1995). A model comparison for daylength as a function of latitude and day of year. Ecological Modelling 80, 87-95.
Gabrielle, B., Recous, S., Tuck, G., Bradbury, N. J. \& Nicolardot, B. (2001). Ability of the SUNDIAL model to simulate the short-term dynamics of ${ }^{15} \mathrm{~N}$ applied to winter wheat and oilseed rape. Journal of Agricultural Science, Cambridge 137, 157-168.

Gallagher, J. N. \& Biscoe, P. V. (1978). Radiation absorption, growth and yield of cereals. Journal of Agricultural Science, Cambridge 91, 47-60.

Gijsman, A. J., Jagtap, S. S. \& Jones, J. W. (2003). Wading through a swamp of complete confusion: how to choose a method for estimating soil water retention parameters for crop models. European Journal of Agronomy 18, 75-105.

Gillett, A. G., Crout, N. M. J., Stokes, D. T., SylvesterBradley, R. \& ScotT, R. K. (2001). An approach to modelling the effect of environmental and physiological factors upon biomass accumulation in winter wheat. Journal of Agricultural Science, Cambridge 136, 369-381.

Greenwood, D. J. \& Barnes, A. (1978). A theoretical model for the decline in the protein content in plants during growth. Journal of Agricultural Science, Cambridge 91, 461-466.

Gregory, P. J., Shepherd, K. D. \& Cooper, P. J. (1984). Effects of fertilizer on root growth and water use of barley in northern Syria. Journal of Agricultural Science, Cambridge 103, 429-438.

Gregory, P. J., McGowan, M. \& Biscoe, P. V. (1978a). Water relations in winter wheat: 2 . Soil water relations. Journal of Agricultural Science, Cambridge 91, 103-116.

Gregory, P. J., McGowan, M., Biscoe, P. V. \& Hunter, B. $(1978 b)$. Water relations of winter wheat: 1 . Growth of the root system. Journal of Agricultural Science, Cambridge 91, 91-102.

Gregory, P. J., Marshall, B. \& Biscoe, P. V. (1981). Nutrient relations in winter wheat. 3. Nitrogen uptake, photosynthesis of flag leaves and translocation of nitrogen to grain. Journal of Agricultural Science, Cambridge 96, 539-547.

Hadjichristodoulou, A., Della, A. \& Photiades, J. (1977). Effect of sowing depth on plant establishment, tillering capacity and other agronomic characters of cereals. Journal of Agricultural Science, Cambridge 89, 161-167.

Hamer, P. J. C. (1995). Modelling the effects of sowing date and plant density on the yield and timing of development of Brussels sprouts (Brassica oleracea). Journal of Agricultural Science, Cambridge 124, 253-263.

Hamer, P. J. C., Carr, M. K. V. \& Wright, E. (1994a). Crop production and water-use. II. The development and validation of a water-use model for sugarbeet. Journal of Agricultural Science, Cambridge 123, 15-24.

Hamer, P. J. C., Carr, M. K. V. \& Wright, E. (1994b). Crop production and water-use. III. The development and validation of a water-use model for potato. Journal of Agricultural Science, Cambridge 123, 299-311.

HANFT, J. M. \& WYCH, R. D. (1982). Visual indicators of physiological maturity of hard red spring wheat. Crop Science 22, 584-588.

Haun, J. R. (1973). Visual quantification of wheat development. Agronomy Journal 65, 116-119.

Heinemann, A. B., Hoogenboom, G. \& Chojnicki, B. (2002). The impact of potential errors in rainfall observation on the simulation of crop growth, development and yield. Ecological Modelling 157, 1-21.

Holst, N. (2005). Recursive density equivalents: An improved method for forecasting yield loss caused by mixed 
weed populations. Journal of Agricultural Science, Cambridge 143, 293-298.

Ilyas, M. (1983). Solar position programs: Refraction, sidereal time and sunset/sunrise. Solar Energy 31, 437-438.

Ilyas, M. (1984a). Reply to B. J. Wilkinson's letter on 'Solar position programs: refraction, sidereal time and sunset/sunrise'. Solar Energy 33, 383.

Ilyas, M. (1984b). Reply to comments by Dr. D. J. B. Pascoe. Solar Energy 34, 206.

Janssen, P. H. M. \& Heuberger, P. S. C. (1995). Calibration of process-oriented models. Ecological Modelling 83, 55-66.

Jones, C. A. \& KinIRY, J. R. (1986). CERES-Maize. A Simulation Model of Maize Growth and Development. College Station, TX: Texas A\&M University Press.

Kage, H., Alt, C. \& Stutzel, H. (2003). Aspects of nitrogen use efficiency of cauliflower I. A simulation modelling based analysis of nitrogen availability under field conditions. Journal of Agricultural Science, Cambridge 141, $1-16$.

Kambezidis, H. D. \& Papanikolaou, N. S. (1990). Solar position and atmospheric refraction. Solar Energy 44, $143-144$.

Kambezidis, H. D. \& Tsangrassoulis, A. E. (1993). Solar position and right ascension. Solar Energy 50, 415-416.

Kaur, P. \& Hundal, S. S. (1999). Forecasting growth and yield of groundnut (Arachis hypogaea) with a dynamic simulation model 'PNUTGROW' under Punjab conditions. Journal of Agricultural Science, Cambridge 133, 167-173.

Keady, T. W. J., Mayne, C. S. \& Fitzpatrick, D. A. (2000). Prediction of silage feeding value from the analysis of the herbage at ensiling and effects of nitrogen fertilizer, date of harvest and additive treatment on grass silage composition. Journal of Agricultural Science, Cambridge 134, 353-368.

Kebreab, E., France, J., Ellis, R. H. \& Garforth, C. (2000). An evaluation of uptake and developmental impact in the semi-arid tropics of four crop production models. Journal of Agricultural Science, Cambridge 134, 173-180.

Kernich, G. C., Shafer, G. A. \& Halloran, G. M. (1995). Barley development as affected by rate of change of photoperiod. Journal of Agricultural Science, Cambridge 124, 379-388.

Kirby, E. J. M. (1974). Ear development in spring wheat. Journal of Agricultural Science, Cambridge 82, 437-447.

Kirby, E. J. M. (1992). A field study of the number of main shoot leaves in wheat in relation to vernalization and photoperiod. Journal of Agricultural Science, Cambridge 118, 271-278.

Kirby, E. J. M. \& FARIS, D. G. (1972). The effect of plant density on tiller growth and morphology in barley. Journal of Agricultural Science, Cambridge 78, 281-288.

Kirby, E. J. M. \& Wrightman, R. M. (1997). Discrepancies between observed and predicted growth stages in wheat. Journal of Agricultural Science, Cambridge 129, 379-384.

Kirby, E. J. M., Apppleyard, M. \& Simpson, N. A. (1994). Coordination of stem elongation and Zadoks growth stages with leaf emergence in wheat and barley. Journal of Agricultural Science, Cambridge 122, 21-29.

Kirby, E. J. M., Porter, J. R., Day, W., Adam, J. S., Apppleyard, M., Ayling, S., Baker, C. K., Belford, R. K., Biscoe, P. V., Chapman, A., Fuller, M. P., Hampson, J., Hay, R. K. M., Matthews, S., Thompson, W. J., Weir, A. H., Willington, V. B. A. \& Wood, D. W. (1987). An analysis of primordium initiation in Avalon winter wheat crops with different sowing dates and at nine sites in England and Scotland. Journal of Agricultural Science, Cambridge 109, 123-134.

Kocabas, Z., Mitchell, R. A. C., Craigon, J. \& Perry, J. N. (1993). Sensitivity analyses of the ARCWHEAT1 crop model: The effects of changes in radiation and temperature. Journal of Agricultural Science, Cambridge 120, $149-158$.

LARGE, E. C. (1954). Growth stages in cereals: illustration of the Feekes Scale. Plant Pathology 3, 128-129.

LegG, B. J., Day, W., Lawlor, D. W. \& Parkinson, K. J. (1979). The effects of drought on barley growth: Models and measurements showing the relative importance of leaf area and photosynthetic rate. Journal of Agricultural Science, Cambridge 92, 703-716.

Lombnaes, P. \& Singh, B. R. (2003). Predicting Zn and $\mathrm{Cu}$ status in cereals - potential for a multiple regression model using soil parameters. Journal of Agricultural Science, Cambridge 141, 349-357.

McGowan, M., Blanch, P., Gregory, P. J. \& Haycock, D. J. (1984). Water relations of winter wheat. 5: The root system and osmotic adjustment in relation to crop evaporation. Journal of Agricultural Science, Cambridge 102, 415-425.

McMaster, G. S. \& Wilhelm, W. W. (1997). Growing degree-days: one equation, two interpretations. Agricultural and Forest Meteorology 87, 291-300.

McMaster, G. S. \& Wilhelm, W. W. (2003). Phenological responses of wheat and barley to water and temperature: improving simulation models. Journal of Agricultural Science, Cambridge 141, 129-147.

McMaster, G. S., Klepper, B., Rickman, R. W., Wilhelm, W. W. \& Willis, W. O. (1991). Simulation of shoot vegetative development and growth of unstressed winter wheat. Ecological Modelling 53, 189-204.

McMaster, G.S., Wilhelm, W. W. \& Morgan, J. A. (1992). Simulating winter wheat shoot apex phenology. Journal of Agricultural Science, Cambridge 119, 1-12.

Michalsky, J. J. (1988a). The astronomical almanac's algorithm for approximate solar position (1950-2050). Solar Energy 40, 227-235.

Michalsky, J. J. (1988b). Errata. Solar Energy 41, 113.

Michalsky, J. J. (1989). Errata. Solar Energy 43, 323.

Moot, D. J., Jamieson, P. D., Henderson, A. L., Ford, M. A. \& Porter, J. R. (1996). Rate of change in harvest index during grain-filling of wheat. Journal of Agricultural Science, Cambridge 126, 387-395.

Muir, L. R. (1983). Comments on 'The effect of atmospheric refraction in the solar azimuth'. Solar Energy 30, 295.

Mulholland, B. J., Craigon, J., Black, C. R., Stokes, D. T., Zhang, P., Colls, J. J. \& Atherton, J. G. (1997). Timing of critical developmental stages and leaf production in field-grown spring wheat for use in crop models. Journal of Agricultural Science, Cambridge 129, 155-161. 
Nain, A. S., Dadhwal, V. K. \& Sing, T. P. (2004). Use of CERES-wheat model for wheat yield forecast in central Indo-Gangetic Plains of India. Journal of Agricultural Science, Cambridge 142, 59-70.

Ntare, B. R., Williams, J. H. \& Dougbedji, F. (2001). Evaluation of groundnut genotypes for heat tolerance under field conditions in a Sahelian environment using a simple physiological model for yield. Journal of Agricultural Science, Cambridge 136, 81-88.

Pal, R., Kapoor, A. K., Poonia, S. R. \& RaJ, M. (1990). Simple water-balance models for simulating moisture, salinity, and sodicity profiles in soil under wheat. Journal of Agricultural Science, Cambridge 115, 163-171.

Pascoe, D. J. B. (1984). Comments on 'Solar position programs: refraction, sidereal time and sunset/sunrise'. Solar Energy 34, 205-206.

Phillips, M. S., Trudgill, D. L., Hackett, C. A., HanCock, M., Holliday, J. M. \& Spaull, A. M. (1998). A basis for predictive modelling of the relationship of the potato yield to population density of potato cyst nematode, Globodera pallida. Journal of Agricultural Science, Cambridge 130, 45-51.

Porter, J. R. (1984). A model of canopy development in winter wheat. Journal of Agricultural Science, Cambridge 102, 383-392.

Porter, J. R., Kirby, E. J. M., Day, W., Adam, J. S., Apppleyard, M., Ayling, S., Baker, C. K., Beale, P., Belford, R. K., Biscoe, P. V., Chapman, A., Fuller, M. P., Hampson, J., Hay, R. K. M., Hough, M. N., Matthews, S., Thompson, W. J., Weir, A. H., Willington, V. B. A. \& Wood, D. W. (1987). An analysis of morphological development stages in Avalon winter wheat crops with different sowing dates and at ten sites in England and Scotland. Journal of Agricultural Science, Cambridge 109, 107-121.

Ritchie, S. W., Hanway, J. J. \& Benson, G. O. (1997a). How a Corn Plant Develops. Special Report No. 48. Ames, IA, USA: Iowa State University of Science and Technology, Cooperative Extension Service.

Ritchie, S. W., Hanway, J. J., Thompson, H. E. \& Benson, G. O. (1997b). How a Soybean Plant Develops. Special Report No. 53. Ames, IA: Iowa State University of Science and Technology, Cooperative Extension Service.

Saxton, K. E., Rawls, W. J., Romberger, J. S. \& PAPENDICK, R. I. (1986). Estimating generalized soil-water characteristics from texture. Soil Science Society of America Journal 50, 1031-1036.

Siddons, P. A., Jones, R. J. A., Hollis, J. M., Hallett, S. H., Huyghe, C., Day, J. M., Scott, T. \& Milford, G. F. J. (1994). The use of a land suitability model to predict where autumn-sown, determinate genotypes of the white lupin (Lupinus albus) might be grown in England and Wales. Journal of Agricultural Science, Cambridge 123, 199-205.

Singh, V. P., Singh, M. \& Kairon, M. S. (1984). Physiological maturity in Aestivum wheat: visual determination. Journal of Agricultural Science, Cambridge 102, $285-287$.

Slafer, G. A. (1996). Differences in phasic development rate amongst wheat cultivars independent of responses to photoperiod and vernalization. A viewpont of the intrinsic earliness hypothesis. Journal of Agricultural Science, Cambridge 126, 403-419.
Smith, P, Falloon, P. D., Korschens, M., Shevtsova, L. K., Franko, U., Romanenkov, V., Coleman, K., Rodionova, V., Smith, J. U. \& Schramm, G. (2002). EuroSOMNET - a European database of long-term experiments on soil organic matter. Journal of Agricultural Science, Cambridge 138, 123-134.

Spencer, J. W. (1989). Letter to the Editor. Solar Energy 42, 353.

Streck, N. A., Weiss, A., Xue, Q. \& Baenziger, P. S. (2003). Improving predictions of developmental stages in winter wheat: a modified Wang and Engel model. Agricultural and Forest Meteorology 115, 139-150.

Thompson, N. (1981). Modelling the field drying of hay. Journal of Agricultural Science, Cambridge 97, 241-260.

Thorne, G. N. \& Wood, D. W. (1988). Contributions of shoot categories to growth and yield of winter wheat. Journal of Agricultural Science, Cambridge 111, 285-294.

Towner, G. D. (1983). A theoretical examination of Burns' (1975) equation for predicting the leaching of nitrate fertilizer applied to a soil surface. Journal of Agricultural Science, Cambridge 100, 293-298.

Travis, K. Z. (1987). Use of a simple model to study factors affecting the size distribution of tubers in potato crops. Journal of Agricultural Science, Cambridge 109, 563-571.

Walraven, R. (1978). Calculating the position of the sun. Solar Energy 20, 393-397.

Walraven, R. (1979). Erratum. Solar Energy 22, 195.

Weightman, R. M., Kirby, E. J. M., Sylvester-Bradley, R., Scott, R. K., Clare, R. W. \& Gillett, A. (1997). Prediction of leaf and internode development in wheat. Journal of Agricultural Science, Cambridge 129, 385-396.

Weir, A. H., Bragg, P. L., Porter, J. R. \& Rayner, J. H. (1984). A winter wheat crop simulation model without water or nutrient limitations. Journal of Agricultural Science, Cambridge 102, 371-382.

Weiss, A. \& Hays, C. J. (2005). Calculating daily mean air temperatures by different methods: implications from a non-linear algorithm. Agricultural and Forest Meteorology 128, 57-65.

WILKINSON, B. J. (1981). An improved FORTRAN program for the rapid calculation of solar position. Solar Energy 27, 67-68.

Wilkinson, B. J. (1983). The effect of atmospheric refraction on the solar azimuth. Solar Energy 30, 295.

Wilkinson, B. J. (1984). Re: 'Solar position programs: refraction, sidereal time and sunset/sunrise'. Solar Energy 33, 383.

Willey, R. W. \& Holliday, R. (1971). Plant population and shading studies in barley. Journal of Agricultural Science, Cambridge 77, 445-452.

Wright, E., Carr, M. K. V. \& Hamer, P. J. C. (1997). Crop production and water-use. IV. Yield function for sugar beet. Journal of Agricultural Science, Cambridge 129, 33-42.

Wright, E., Carr, M. K. V. \& Hamer, P. J. C. (1994). Crop production and water-use. I. A model for estimating crop water-use with limited data. Journal of Agricultural Science, Cambridge 123, 9-13.

Wurr, D. C. E., Edmondson, R. N. \& Fellows, J. R. (2000). Climate change, a response surface study of the effects of $\mathrm{CO}_{2}$ and temperature on the growth of French 
beans. Journal of Agricultural Science, Cambridge 135, 379-387.

Zadoks, J. C., Chang, T. T. \& Konzak, C. F. (1974). A decimal code for the growth stages of cereals. Weed Research 14, 415-421.
ZAhedi, M. \& Jenner, C. F. (2003). Analysis of effects in wheat of high temperature on grain filling attributes estimated from mathematical models of grain filling. Journal of Agricultural Science, Cambridge 141, 203-212.

\section{APPENDIX}

\section{APPENDIX 1}

The five methods used to calculate daily mean air temperature $(\bar{T})$.

Hourly

$$
\bar{T}=\left(\sum_{i=1}^{i=24} T i\right) / 24
$$

where $i$ is the hour

$\mathrm{Ti}$ is the hourly mean air temperature for hour i $\left({ }^{\circ} \mathrm{C}\right)$

Weighted

$$
\bar{T}=\left(T_{0700}+T_{1400}+2 * T_{2100}\right) / 4
$$

where $T_{0700}$ is the hourly mean air temperature for 0700 local time $\left({ }^{\circ} \mathrm{C}\right)$

$T_{1400}$ is the hourly mean air temperature for 1400 local time $\left({ }^{\circ} \mathrm{C}\right)$

$T_{2100}$ is the hourly mean air temperature for 2100 local time $\left({ }^{\circ} \mathrm{C}\right)$

Mean 3 hour

$$
\bar{T}=\left(\sum_{i=1}^{i=8} T_{3} i\right) / 8
$$

where $\mathrm{i}$ is every 3 hours $(0300,0600, \ldots 2100,2400$ local time)

$T_{3}$ is the 3 hour mean temperature for hour i $\left({ }^{\circ} \mathrm{C}\right)$

CERES (Jones \& Kiniry 1986)

$$
\bar{T}=\left\{\sum_{i=1}^{i=8} T_{c} i\right\} / 8
$$

(4) More details about this algorithm are given in Streck et al. (2003).

$$
T_{c} i=\operatorname{Tmin}+\operatorname{tmfac}_{i}(\operatorname{Tmax}-\operatorname{Tmin})\left({ }^{\circ} \mathrm{C}\right)
$$

Tmin is the daily minimum temperature $\left({ }^{\circ} \mathrm{C}\right)$

Tmax is the daily maximum temperature $\left({ }^{\circ} \mathrm{C}\right)$ tmfac $_{i}=0 \cdot 931+0 \cdot 114 \mathrm{i}-0 \cdot 0703 \mathrm{i}^{2}+0 \cdot 0053 \mathrm{i}^{3}$; for $\mathrm{i}=1$ to 8

$\operatorname{Max} / \min$

$$
\bar{T}=(\operatorname{Tmin}+\operatorname{Tmax}) / 2
$$

where Tmin is the daily minimum temperature $\left({ }^{\circ} \mathrm{C}\right)$

Tmax is the daily maximum temperature $\left({ }^{\circ} \mathrm{C}\right)$

\section{APPENDIX 2}

The temperature component of a non-linear algorithm for plant development.

$$
\begin{gathered}
\mathrm{f}(\mathrm{T})=\frac{2(T-T n)^{\alpha}(T o p t-T n)^{\alpha}-(T-T n)^{2 \alpha}}{(T o p t-T n)^{2 \alpha}} \\
\text { if } T n \leqslant T \leqslant T x \\
\mathrm{f}(\mathrm{T})=0 ; \text { if } T<T n \text { or } T>T x \\
\alpha=\ln 2 / \ln [(T x-T n) /(T o p t-T n)] \\
\operatorname{Rdev}=\operatorname{Rmax} \mathrm{f}(\mathrm{T})
\end{gathered}
$$

where $T$ is the temperature $\left({ }^{\circ} \mathrm{C}\right)$

$T n$ is the minimum cardinal temperature

$T x$ is the maximum cardinal temperature

Topt is the optimum cardinal temperature

Rmax is the maximum development rate 